AKSIOLOGI : JURNAL

PENDIDIKAN DAN ILMU SOSIAL
Aksiologi : Jurnal Pendidikan

dan Ilmu Sosial Volume : 1 No.2 (2021)

E-ISSN : 2747-2752 / P-ISSN : 2774-5686

\title{
Penggunaan Smartphone Sebagai Sumber Belajar Anak Pada Masa Covid-19 Di Komplek Bulakindo Kota Banjarmasin
}

\author{
${ }^{1}$ Rahmat Nur, ${ }^{2}$ Fatimah Azis, ${ }^{3}$ Yuli Apriati \\ ${ }^{1}$ Pendidikan Sosiologi, Universitas Lambung Mangkurat \\ ${ }^{2}$ Pendidikan Sosiologi, Universitas Muhammadiyah Makassar \\ ${ }^{3}$ Pendidikan Sosiologi, Universitas Lambung Mangkurat \\ Email : rahmat.nur@ulm.ac.id
}

\begin{abstract}
The development of cellphone technology can be seen from the breakthrough of a new, more sophisticated type of cellphone, namely the smartphone. Today smartphones are important items in daily activities including learning activities. Informants as sources of information were selected using purposive sampling technique. Data mining was carried out by observation, in-depth interviews with selected informants and diaries are one of the important data sources in the research used. The research results will be analyzed by phenomenological analysis. The results show that: (1) the function of smartphones as a learning resource during the Covid 19 pandemic is to function as a communication tool for the learning process, assisting teachers and children in teaching and doing or completing assignments given by the teacher; (2) the children's response liked smartphones to be used as a learning resource because they were easy to use and fast to find the answers they were looking for; Children ask a lot of questions to the teacher because children are confused about finding suitable answers and language that is difficult to understand. The teacher's response is always to supervise children when using a smartphone to browse the internet.
\end{abstract}

Keywords : Learning Resources, Function, Response, Benefits.

\begin{abstract}
Abstrak
Perkembangan teknologi handphone dapat dilihat dari terobosan handphone jenis baru yang lebih canggih yaitu smartphone. Zaman sekarang smartphone menjadi barang penting dalam kegiatan sehari-hari termasuk kegiatan pembelajaran. Informan sebagai sumber informasi dipilih dengan menggunakan teknik purposive sampling. Penggalian data dilakukan dengan observasi, wawancara secara mendalam (in-depth interview) terhadap informan yang telah terpilih dan Catatan harian merupakan salah satu sumber data yang penting di dalam penelitian yang digunakan. Hasil penelitian akan dianalisis dengan analisis fenomenologi. Hasil penelitian menunjukkan bahwa:(1) fungsi smartphone sebagai sumber belajar dimasa Pandemi covid 19 yaitu dapat berfungsi sebagai alat komunikasi untuk untuk proses pembelajaran, Membantu guru dan anak-anak dalam mengajar dan mengerjakan atau menyelesaikan tugas yang diberikan oleh guru; (2) respon anak-anak menyukai smartphone digunakan sebagai sumber belajar karena mudah untuk digunakan dan cepat untuk menemukan jawaban yang dicari; anak-anak banyak mengajukan pertanyaan kepada guru karena anak-anak bingung menemukan jawaban yang cocok dan bahasa yang sulit dipahami. Respon guru selalu mengawasi anak-anak saat mengunakan smartphone untuk melakukan browsing di internet'
\end{abstract}

Kata Kunci : Sumber Belajar, Fungsi, Respon, Manfaat 


\section{PENDAHULUAN}

Perkembangan teknologi informasi dan komunikasi pada saat ini mengalami kemajuan yang sangat pesat dan pengaruhnya terlihat pada berbagai bidang seperti bidang kesehatan, ekonomi dan pendidikan. Teknologi adalah salah satu bidang yang memiliki tingkat kemajuan yang signifikan di berbagai belahan dunia bahkan sekarang teknologi sudah tidak bisa dipisahkan dalam kegiatan sehari-hari yang dijalankan oleh masyarakat. Teknologi merupakan alat bantu yang memudahkan masyarakat untuk melakukan aktivitas seperti teknologi komputer, radio, televisi dan terutama handphone. Teknologi handphone merupakan teknologi yang membantu masyarakat untuk berkomunikasi dengan lebih mudah, pemberian informasi dengan akses yang mudah karena teknologi handphone ini berkembang sesuai kondisi zaman yang mengharuskan masyarakat untuk cepat mendapatkan informasi guna mempermudah aktivitasnya. Handphone yang mengalami perkembangan dapat dilihat dari adanya terobosan baru yaitu telepon pintar atau yang biasa disebut smartphone.

Pada era Covid-19 Smartphone memasuki perkembangan yang lebih canggih dengan adanya terobosan yang lebih canggih yaitu smartphone atau telepon pintar. Handphone atau smartphone tidak hanya digunakan sebagai alat komunikasi saja seperti telepon dan sms (short message service), melainkan digunakan juga dalam kebutuhan sosial, pekerjaan, dan pendidikan. Tidak dipungkiri bahwa di perkembangan smartphone menjadi trend di kalangan masyarakat khususnya para pelajar.

Dampak covid-19 merubah pembelajaran tatap muka menjadi pembelajaran jarak jauh atau pembelajaran online. Dengan pembelajaran online para guru menggunakan berbagai fasilitas belajar, guru menggunakan e-learning dengan komptensi yang dimiliki guru dalam penggunaan e learning (Awouters \& Jans, 2009), seperti menggunakan elearning dengan google classroom (Bhat et al., 2018), penggunaan elearning dalam online menjadi dinamika tersendiri dalam pembelajaran online saat ini di Indonesia (Mansyur, 2020), bukan halnya di Indonesia termasuk di negara Thailand juga menggunakan elearning dengan memperhatikan halhal managemen e-learning untuk membantu pelaksanaan pembelajaran e-learning di Thailand (Vicheanpanya,2014) Penggunaan smartphone sebagai alat dan sumber belajar di masa pandemi covid-19 membuktikan bahwa tekhnologi ini memberi warna dan kebutuhan dasar para anak-anak saat ini.

Hal ini dibuktikan dengan Penelitian yang dimuat di jurnal IBTIDA yang dilakukan oleh Salehuddin,Muhammad,; Marnia; Haryat, Anak-anak SD Menggunakan Smartphone Dalam Pembelajaran Online ( 2020, Hal. 229-241). Penelitian ini menemukan Anak-anak SD menggunakan smartphone dalam belajar dalam kategori "baik" untuk belajar, mengerjakan dan pengumpulkan tugas, alat menelusuri sumber belajar elektornik dan digital, mampu berdiskusi dengan teman sebaya dan semua merasa puas menggunakan smartphone dalam aktivitas proses pembelajaran online.

Salah satu lokasi dalam penelitian ini adalah komplek bulakindo Kota Banjarmasin, berdasarkan observasi awal yang dilakukan peneliti mewawancarai Ketua RT.22 Komp. Bulakindo dan menyampaikan bahwa selama covid 19 menyerang satu tahun terakhir dan anakanak dirumahkan maka saya dan warga di bulakindo sepakat untuk menyediakan 
layanan jaringan internet atau wifi yang memudahkan anak-anak untuk mengakses internet dengan mudah melalui smartphone mereka. Layanan ini dipusatkan di Langgar Komplek, agar para anak-anak juga dismping belajar online juga bisa menjaga ibadah.

Penggunaan Samrtphone ini menjadi menarik peneliti untuk melihat sejauh mana pengaruh dan fungsi serta respon para guru anak-anak sekolah di komplek bulakindo menggunakan sesuai dengan asa kebermanfaatan teknologi di masa pandemi covid-19.

\section{METODE}

Penelitian ini meengunakan metode kualitatif, permasalahan masih bersifat holistik, kompleks, dinamis dan penuh makna sehingga tidak mungkin data pada situasi sosial tersebut dijaring dengan metode penelitian kuantitatif dengan instrument seperti test, kuesioner. Metode penelitian kualitatif digunakan untuk mendapatkan data yang mendalam, dan data yang mengandung makna. Penelitian kualitatif tidak menekankan pada generalisasi, tetapi lebih menekankan pada makna. Melalui penelitian kualitatif. Untuk memperoleh pemahaman yang mendalam penggunaan smartphone dimasa covid-19. Pengambilan metode kualitatif sebagai metode penelitian, terkait dengan pendekatan yang akan dipakai dalam penelitian ini yaitu pendekatan phenomenologis. Menurut Schultz (Holstein dan Gubrium, 1994) fenomenologi melihat individu mendekati dunia sosial dengan suatu stock of knowledge. Stock of kowladge ini terdiri dari konstruksi dan kategori sosial yang terbentuk secara sosial dalam suatu komunitas, dan diterapkan ke berbagai aspek pengalaman, sehinggga aspekaspek pegalaman ini menjadi bermakna (Schultz dalam Holstein and Gubrium, 1994).
Penelitian ini akan dilaksanakan di Komplek Bulakindo Kota Banjarmasin, Kalimantan Selatan. Subyek penelitian ini adalah para anak sekolah di komplek bulakindo kota banjarmasin. Informan sebagai sumber informasi yang terpilih dalam penelitian ini ditentukan dengan menggunakan teknik purposive sampling yaitu informan yang dipilih berdasarkan pertimbangan-pertimbangan tertentu dengan sifat-sifat yang bisa diketahui sebelumnya. Untuk kepentingan pengumpulan data, peneliti akan melakukan kegiatan tersebut dengan beberapa cara. Pertama, observasi dengan melihat kegiatan belajar anakanak di komplek bulakindo. Data yang di dapat dari lapangan selanjutnya akan dilakukan proses horizonalizing data dan menganggap setiap horizon atau pernyataan yang sesuai dengan topik dan pertanyaan memiliki nilai yang sama. Melalui pernyataan yang terhorizonalkan, makna dan unit-unit makna di daftar. Daftar makna dan unit-unit makna ini kemudian dikategorikan ke dalam tema-tema dan membuang pernyataan yang tumpang tindih dan diulang-ulang. Pengkategorian tema dan makna ini digunakan untuk membangun gambaran tekstur dari peristiwa. Dari gambaran tekstur, gambaran struktural dan integrasi tekstur dan struktur terhadap makna-makna dan esensi-esensi inilah fenomena.

\section{HASIL DAN PEMBAHASAN}

\section{A. Fungsi Smartphone Sebagai alat Sumber Belajar pada masa Pandemi Covid-19}

Perbedaan yang sangat signifikan dirasakan oleh guru dan anak-anak saat ini. Masa pandemic covid memrikan banyak pembelajaran. Disaat proses belajar mengajar Online berlangsung akan terjadi adanya interaksi antara guru dan anak-anak dimana interaksi ini terjalin dengan adanya komponen 
penting lainnya. Komponen penting yang lain adalah materi pelajaran, alat bantu belajar, metode, dan situasi pembelajaran yang mendukung berlangsungnya proses belajar sehingga mencapai tujuan yang sudah ditentukan. Komponen seperti alat bantu belajar menjadi salah satu komponen penting yang harus disiapkan oleh guru saat ingin melakukan kegiatan proses belajar mengajar. smartphone sebagai alat dan internet dapat dijadikan sebagai sumber belajar yang membantu guru dan anakanak saat proses belajar mengajar berlangsung.(Nur, 2020b)

$$
\text { Menurut Indrajit (Warsita, }
$$

2008:136) fungsi teknologi informasi dan komunikasi dalam pendidikan dapat dibagi menjadi tujuh fungsi, salah satunya sebagai alat bantu pembelajaran atau media pembelajaran. Pada penelitian ini masalah yang pertama adalah fungsi smartphone sebagai media pembelajaran dalam proses belajar anakanak secara Online. Berdasarkan hasil observasi dan wawancara dapat disimpulkan bahwa fungsi dari penggunaan smartphone sebagai sumber belajar dalam proses belajar Online yakni berfungsi sebagai alat dasar komunikasi antara guru dan anak-anak , sebagai penunjang untuk mencari materi, alat bantu mengerjakan tugas. Informasi mengenai fungsi yang diperoleh dari penggunaan smartphone sebagai sumber belajar diungkapkan oleh ibu Ridha Fithria, S.Pd salah satu guru yang mengajar salah satu dari anak-anak yang tinggal di komplek bulakindo.

Menurut warsita (2008:212) sumber belajar dapat dibedakan menjadi dua jenis yaitu sumber belajar yang dirancang dan sumber belajar yang sudah tersedia dan tinggal dimanfaatkan. Sesuai dengan yang dikemukakan mengenai dua jenis sumber belajar maka smartphone dengan menghubungkan pada jaringan internet merupakan sumber belajar yang sudah tersedia dan tinggal di manfaatkan, karna smartphone dan internet tidak dirancang secara khusus atau dikembangkan untuk keperluan pembelajaran. Tiga fungsi yang didapat dari penggunaan smartphone sebagai sumber belajar saat proses belajar berlangsung sesuai dengan pendapat yang dikemukakan oleh Winn (Warsita, 2008:127) bahwa peranan media dalam pendidikan yaitu sebagai : (1) media pembelajaran, yang dalam hal ini berfungsi sebagai penyampaian pesan khusus; (2) sebagai pembentuk lingkungan perantara, dimana media membantu peserta didik melakukan eksplorasi dan membentuk pemahaman suatu pengetahuan; dan (3) pengembangan kemampuan kognitif, dimana media dipergunakan sebagai model atau perluasan mental kemampuan.

Smartphone yang digunakan sebagai sumber belajar dapat berfungsi sebagai alat penunjang untuk pencarian materi pelajaran. Smartphone yang anakanak miliki saat proses belajar digunakan sebagai alat untuk mencari materi tambahan di internet dengan sumber atau website yang beragam. Mencari materi pembelajaran di internet ini dilakukan karena penjelasan di buku panduan kurang dan dimaksudkan untuk memperluas pemahaman anak-anak terhadap materi yang diajarkan. Pernyataan yang dikemukakan mengenai peranan media dalam pendidikan sesuai dengan fungsi pertama mengenai penggunaan smartphone sebagai sumber belajar online. Fungsi pertama sesuai dengan peranan media pendidikan bagian pertama yaitu media dapat berfungsi sebagai penyampaian pesan khusus. Smartphone dapat dijadikan sebagai media pembelajaran dengan menghubungkan smartphone pada jaringan internet, maka dari itu media smartphone bisa dikatakan memiliki peranan sebagai penyampaian pesan kepada peserta didik seperti media lainnya. Diketahui bahwa internet merupakan jaringan yang memiliki 
sekumpulan informasi mengenai pendidikan seperti materi pelajaran dan soal- soal pelajaran sehingga dapat berguna untuk peserta didik.(Nur, 2020)

Smartphone dapat berfungsi sebagai alat bantu mengerjakan tugas, dalam hal ini guru memberikan tugas dengan memberikan beberapa pertanyaan. Tugas yang diberikan oleh guru terkadang mengharuskan mereka untuk mencari di internet, sehingga guru memperbolehkan anak-anak untuk menggunakan smartphone sebagai alat bantu untuk mengerjakan tugas. Fungsi kedua dari penggunaan smartphone sebagai media pembelajaran sesuai dengan poin kedua mengenai peranan media dalam pendidikan. Poin kedua dari peranan media dalam pedidikan adalah media membantu peserta didik melakukan eksplorasi dan membentuk pemahaman suatu pengetahuan. Smartphone yang digunakan sebagai sumber belajar membantu anak-anak untuk mengerjakan tugas anak-anak. Mengerjakan tugas yang dibeikan oleh guru adalah salah satu bentuk dari proses belajar dan juga dapat memberikan pemahaman kepada anakanak mengenai materi yang sedang dipelajari.

Smartphone juga berfungsi menghilangkan kejenuhan anak-anak saat belajar. Proses belajar mengajar biasanya berlangsung lama, apabila setiap hari guru hanya menggunakan sumber belajar yang sama setiap pelajaran maka anak-anak akan jenuh dan mengurangi semangat anak-anak untuk belajar, untuk mensiasati hal ini, ibu Ridha sudah setahun menggunakan smartphone sebagai sumber belajar. untuk menghilangkan kejenuhan anak dalam belajar tentu banyak hala yg dilakukan, sperti mnegubah metode belajar, menonton video positif, dan memberikan game kepada anak saat proses belajar online berlangsung. Kekuaatan Smartphone sebagai sumber belajar tidak hanya memberikan pemahaman, pengetahuan dan membantu anak-anak mengerjakan tugas tetapi juga dapat membantu untuk menghilangkan kejenuhan anak-anak terhadap proses belajar yang monoton.

Menurut Percival dan Ellington(1984:125) sumber belajar yang digunakan harus dijamin agar cocok, sumber tersebut harus memenuhi ketiga persyaratan yaitu dapat tersedia dengan cepat, memungkinkan anak-anak untuk memacu diri sendiri dan dapat memenuhi berbagai kebutuhan para anak-anak dalam belajar mandiri. Menggunakan smartphone dengan menghubungkannya pada jaringan internet memungkinkan untuk dijadikan sebagai sumber belajar. Smartphone sebagai alat yang mudah dibawa dan digunakan memungkin untuk digunakan sebagai alat bantu belajar anak-anak . Internet yang merupakan jaringan berisi beragam informasi dapat dijadikan sebagai sumber belajar anak-anak . Smartphone dengan jaringan internet memungkinkan untuk digunakan sebagai sumber karena smartphone mudah untuk diginakan oleh anak-anak dan mengakses internet juga mudah dilakukan.

Fasilitas yang disiapkan di momplek bulakindo tentu membantu anak untuk mengakses pembelajaran sehingga mengakses internet menggunakan smartphone dapat memberikan keuntungan bagi guru dan anak-anak. Prosesnya penggunaan smartphone sebagai sumber belajar, guru tidak bisa hanya sekedar mengintruksikan anak-anak untuk menggunakan smartphone-nya sebagai alat untuk mencari materi atau biasa dikenal dengan browsing. Guru juga harus mempersiapkan rencana pembelajaran yang akan dilaksanakan dengan menggunakan smartphone tersebut, apalagi akhir-akhir ini anakanak sdh mulai jenuh dengan keadaan pembelajaran online. 


\section{B. Respon Dari Guru dan Anak-anak yang Menggunakan Smartphone dalam Proses Belajar Online di masa Pandemi Covid-19}

Respon yaitu reaksi yang dimunculkan peserta didik ketika belajar, yang juga dapat berupa pikiran, perasaan, atau gerakan/tindakan. Berdasarkan pendapat ahli diatas diketahui bahwa dalam proses belajar selalu ada interaksi antara stimulus dan respon. Stimulus adalah kegiatan apa saja yang diberikan oleh guru yang dapat merangsang anak-anak dalam kegiatan belajar seperti pikiran, perasaan dan halhal yang dapat ditangkap melaui indera. Respon merupakan reaksi dari anakanak yang terjadi akibat stimulus yang diberikan oleh guru. Reaksi anak-anak bisa berupa pikiran, perasaan, gerakan/tindakan atau perubahan tingkah laku yang dapat diamati dan dapat diukur.(Nur, 2020b)

Menggunakan smartphone sebagai sumber belajar saat kegiatan belajar mengajar di masa pandemic Covid-19 akan mendapatkan respon atau reaksi dari anak-anak maupun guru. Berdasarkan observasi dan wawancara yang telah dilakukan pada anak di komplek Bulakindo mengenai penggunaan smartphone sebagai sumber belajar, dapat dikatakan bahwa respon yang diberikan oleh guru dan anak-anak saat menggunakan smartphone sebagai sumber belajar adalah anak-anak menyukai smartphone sebagai sumber belajar dan anak-anak banyak mengajukan pertanyaan kepada guru.

Menurut Steven M. Chafe (Rakhmat, 1999:118) respon dibedakan menjadi tiga bagian yaitu kognitif, afektif, dan konatif (Psikomotorik). Respon pertama yang diberikan guru dan anakanak mengenai penggunaan smartphone sebagai sumber belajar termasuk pada bagian afektif. Afektif adalah respon yang berhubungan dengan emosi, sikap, dan menilai seseorang terhadap sesuatu.
Respon pertama adalah anak-anak menyukai smartphone digunakan sebagai sumber belajar. Diketahui bahwa respon pertama yang diberikan oleh anak-anak adalah emosi yaitu perasaan senang atau suka. Perasaan suka yang timbul karena menurut anak-anak media smartphone mudah untuk digunakan dan saat browsing menggunakan smartphone anak-anak mengungkapkan bahwa anakanak cepat mendapatkan jawaban dari apa yang mereka cari atau tugas yang diberikan oleh guru.

Respon kedua dari anak-anak yaitu perubahan sikap anak-anak yang banyak mengajukan pertanyaan kepada guru termasuk pada bagian afektif juga. Respon kedua termasuk pada bagian afektif karena adanya perubahan sikap yang terjadi pada anak-anak yaitu saat tidak menggunakan media smartphone anak-anak cenderung menyimak guru menjelaskan, hanya beberapa anak-anak saja yang mengajukan pertanyaan kepada guru. Saat guru menggunakan media smartphone sebagai sumber belajar banyak mengajukan pertanyaan kepada guru, hal ini dilakukan anak-anak karena dalam proses mencari jawaban atau materi di website, mereka mengalami kesulitan. Kesulitan yang mereka alami terkadang karena materi yang dicari tidak ditemukan dan terkadang bahasa yang digunakan di website sulit untuk mereka pahami. Sehingga anak-anak bertanya terlebih dahulu kepada guru sebelum mencatatnya di buku tulis komunikasi Aplikasi Whats App

Menurut Suyanto (2004:31-32), ada bermacam-macam tanggapan yaitu salah satunya tanggapan menurut indera yang mengamati. Menggunakan smartphone sebagai sumber belajar mengharuskan anak-anak untuk menggunakan indera mereka seperti telinga, mata, tangan dan banyak lagi. Tanggapan menurut indera yang mengamati terbagi menjadi tiga bagian yaitu tanggapan auditif, tanggapan visual, 
dan tanggapan perasa. Respon dari anakanak mengenai penggunaan smartphone sebagai sumber belajar termasuk dalam tanggapan visual dan tanggapan perasa. Tanggapan visual adalah tanggapan terhadap sesuatu yang dilihat, pada kegiatan pembelajaran menggunakan media smartphone anak-anak melihat smartphone mereka. Tanggapan perasa yakni tanggaapan terhadap sesuatu yang dialaminya, karena saat menggunakan media smartphone anak-anak merasa senang.

Menggunakan media smartphone memberikan respon yang beragam, respon dari anak-anak saat menggunakan smartphone sebagai sumber belajar bersifat positif dan negatif. Tujuan dari proses belajar mengajar adalah mendidik Anak-anak untuk lebih cerdas dalam segi pengetahuan dan sikap aktif anak-anak dalam mengikuti pelajaran. Menggunakan media smartphone pada dasarnya membuat anak-anak untuk aktif yaitu aktif dalam hal bertanya kepada guru.

\section{KESIMPULAN}

Fungsi smartphone sebagai sumber belajar dalam proses belajar yang berlangsung pada anak-anak di komplek Bulakindo yaitu; smartphone yang dimiliki dapat digunakan untuk proses pembelajar Online, mencari materi pelajaran tambahan di internet, smartphone juga dapat membantu anakanak untuk mengerjakan tugas yang diberikan oleh guru, tugas yang diberikan oleh guru biasanya tugas individu yaitu tugas tertulis dan tugas kelompok. Fungsi smartphone sebagai sumber belajar yang terakhir dapat menghilangkan kejenuhan anak-anak dalam belajar, aplikasi yang digunakan google browser. Respon yang diberikan guru dan anak-anak mengenai penggunaan smartphone sebagai sumber belajar dalam proses belajar online yaitu; respon yang ditunjukkan oleh anak-anak adalah anak-anak menyukai smartphone digunakan sebagai sumber belajar karena mudah untuk digunakan dan cepat untuk menemukan jawaban yang dicari. Respon selanjutnya dari anakanak adalah saat menggunakan smartphone menyebabakan anak-anak banyak mengajukan pertanyaan kepada guru mengenai materi yang dicari di internet. Respon dari guru yaitu guru selalu mengawasi anak-anak nya dalam menggunakan smartphone agar anakanak tidak melakukan kegiatan lain selain browsing unuk mencari materi.

\section{DAFTAR PUSTAKA}

Ali, Muhammad, 1996. Guru Dalam Proses Belajar Mengajar. Bandung: Sinar Baru Algensindo.

Alisjahbana, Iskandar, 1980. Teknologi dan Perkembangan. Jakarta: Yayasan Idayu. Arsyad, Azhar, 1997. Media Pembelajaran. Jakarta: PT Raja Grafindo Persada.

Association for Educational Communications and Technology (Assosiasi Teknologi Komunkasi Pendidikan)/AECT, 1977. The Definition of Educational Technology. Diterjemahkan dari bahasa Inggris oleh Sadiman, Arif S, et.al. Jakarta: Pusat Antar Universitas di Universitas Terbuka dan CV. Rajawali.

Basrowi dan Suwandi, 2008. Memahami Penelitian Kualitatif. Jakarta: Rineka Cipta. Budiningsih, C Asri. 2005. Belajar dan Pembelajaran. Jakarta: PT Rineka Cipta.

Bungin, Burhan, 2007. Penelitian Kualitatif komunikasi, ekonomi, kebijakan publik, dan ilmu social lainnya. Jakarta: Kencana Prenada Media Group. 
2006. Sosiologi Komunikasi: Teori, Paradigma dan Diskursus Teknologi Komunikasi di Masyarakat. Jakarta: Kencana.

Djamarah, Syaiful Bahri, 2000. Guru dan Anak Didik Dalam Interaksi Edukatif. Jakarta: PT Rineka Cipta.

Gulo,W. 2002. Strategi Belajar Mengajar. Jakarta: PT Grasindo.

Hamalik, Oemar. 2013. Proses Belajar Mengajar. Jakarta: PT Bumi Aksara. Hasibun, J.J dan Moedjiono, 1995. Proses Belajar Mengajar. Bandung

Nur, R. (2020a). Integrasi Nilai Karakter Dalam Pembelajaran Sosiologi Wilayah Sul-Sel Kota. 2(1), 187201.

https://doi.org/https://doi.org/10. 20527/padaringan.v2i1

Nur, R. (2020b). Penerapan Model Pembelajaran Tematik Pada Mata Pelajaran Sosiologi Siswa Kelas XII IPS SMAN 1 Sungguminasa Kabupaten Gowa. 2(3). https://doi.org/https://doi.org/10. 20527/padaringan.v2i3

Miarso, Yusufhadi, 2004. Menyemai Benih Teknologi Pendidikan. Jakarta: Prenada Media Group.

Moleong, Lexi J, 2007. Metodologi Penelitian Kualitatif. Bandung: Remaja Rosdakarya. Percival, Fred dan Henry Ellington, 1988. Teknologi Pendidikan. Jakarta: Rineka Cipta.

Prawiradilaga, Dewi Salma dan Eveline Siregar, 2004. Mozaik Teknologi Pendidikan. Jakarta:

Rakhmat, Jalaluddin, 1999. Psikologi Komunikasi. Bandung: Remaja Rosdakarya
Rusman, Deni Kurniawan dan Cepi Riyana, 2012. Pembelajaran Berbasis Teknologi Informasi dan Komunikasi. Jakarta: PT Raja Grafindo Persada.

Sarwanto, Sarlito Wirawan, 1987. TeoriTeori Psikologi Sosial. Jakarta: Rajawali.

Sadiman, Arief S, et.al, 2007.Media Pendidikan Pengertian, Pengembangan dan pemanfaatannya. Jakarta: PT Raja Grafindo Persada.

Sardiman, 2012. Interaksi dan Motivasi Belajar Mengajar. Jakarta: PT Raja Grafindo Persada.

Anak-anak nto, Victorianus Aries, 2012. Strategi dan Langkah-Langkah Penelitian, Yogyakarta: Graha Ilmu.

Subagyo, Joko, 2004. Metode Penelitian Dalam Teori dan Praktek. Jakarta: Rineka Cipta

Sugiyono, 2013. Memahami Penelitian Kualitatif. Bandung: Alfabeta.

Sutopo, Ariesto Hadi, 2012. Teknologi informasi dan Komunikasi Dalam Pendidikan.ogyakarta: Graha Ilmu.

Suyanto, Agus. 2004. Psikologi Umum. Jakarta: Bumi Aksara.

Syah, Muhibbin. 2003. Psikologi pendidikan (Telaah Singkat Perkembangan Peserta Didik). Jakarta: Rajawali Press.

Usman, Husaini dan Setiady Akbar Purnomo, 2003. Metodologi Penelitian Sosial, Jakarta: PT. Bumi Aksara.

Warsita, Bambang, 2008. Teknologi Pembelajaran Landasan dan Aplikasinya. Jakarta: PT Rineka Cipta. 